\title{
A Semiotic Approach to Understanding Advertisements
}

\author{
By
}

\author{
Amal Zakareya Hal \\ Assistant Lecturer at Faculty of Arts, \\ Port Said University
}

DOI: 10.21608/jfpsu.2021.39413.1013 


\title{
A Semiotic Approach to Understanding Advertisements
}

\begin{abstract}
This research investigates the role of semiotics in comprehending the ideological and cultural symbols utilised in advertisements. The major aim of this study is to examine how the different approaches of semiotics contribute to interpreting the messages decoded in advertisements. Under the broad theory of semiotics, the current research presents Saussure's (1916) dyadic model of the sign as well as Peirce's (1955) triadic model of the sign. Furthermore, this research highlights the predominant role played by advertisements in our society these days. The study also gives an account of Barthes' (1977) categorization of the messages existing in advertisements into linguistic, denotative and connotative. In addition, an overview of van Leeuwen's (2005) social semiotic approach is presented. Findings of the study indicate that advertisements are loaded with signs whose interpretations depend largely on culture and ideology. The study also shows that the aforementioned semiotic approaches can help in revealing how advertisements perpetuate certain ideas and beliefs while ignore others. It indicates that most advertisements try to communicate implicitly the idea of how people are supposed to be.
\end{abstract}

Keywords: semiotics, advertisements, ideology, culture, social semiotics 


\section{المنهج السيميوطيقي في فهم الإعلانات}

المستخلص

تبحـث هـذه الدراسـة دور السـيميوطيقا في فهـم الرمـوز الأيديولوجيـة والثقافيـة المسـتخدمة في

الإعلانات. والهدف الرئيسي لهذه الدراسة هو فحص كيفية مشاركة المناهج المختلفة للسيميوطيقافي تفسير الرسائل المكنونة في الإعلانات. ففي ظل نظريـة السيميوطيقا تقدم هذه الدراسة نموذج سوسير (1916) الثنائي للعلامة بالإضافة إلى نموذج بيرس (1955) الثلاثي للعلامة. وعلاوة على ذلك تسلط هذه الدراسـة الضـوء على الدور السـائد الذي تلعبـه الإعلانـات في مجتمعنـا هذه الأيـام. وتقدم الدراسـة أيضـاً سـرداً لتصـنيف بـارثيس (1977) للرسـائل الموجودة في الإعلانـات إلى رسـائل لغويـة ، رسـئل دلاليـة، رسـائل ضمنية. فضـلاً عن ذلك يتم عرض لمحة عن نهج فان ليوين (2005) عن السيميوطيقا الاجتماعية. وتشير نتائج هذه الدراسـة إلى كون الإعلانـات حافلـة بالعلامـات التي تعتمد تفسيراتها بشكل كبير على الثقافة والأيديولوجيا ، كمـا توضـح هذه الدراسـة أن المداخل السيميوطيقية سـالفة الذكر مسن الممكن أن تساعد في كثف كيفية ترسيخ الإعلانات لمفاهيم وأفكار بعينها في حين تجاهل الأخرى. وتوضح أيضـاً أن معظـم الإعلانـات تحـاول ضــنياً توصـيل فكرة عـن الشكل المفترض الذي ينبغـي أن يكـون عليـه الأشخاص.

الكلمات المفتاحية: السيميوطيقا، الاعلانات ، الأيديولوجيا ، الثقافة ، السيميوطيقا الاجتماعية 


\section{$\underline{\text { Introduction }}$}

Advertisements have become an inescapable part of everyone's life. Nowadays, we are deluged with different kinds of advertisements communicating numerous messages. Furthermore, advertisements contain a lot of signs which contribute to conveying various meanings and ideologies. With the help of semiotics, those encoded meanings can be decoded and those signs can be anayzed.

\section{Aim of the study}

This research aims to investigate the various semiotic approaches to advertisements. It also aims to show the way whereby advertisements are analyzed with respect to semiotics. Moreover, it examines how the different approaches of semiotics can help in revealing the messages underlying advertisements.

\section{$\underline{\text { Research questions }}$}

The current research attempts to answer the following questions:

1. What are the different semiotic approaches involved in the study of advertisements?

2. How can advertisements be analyzed from a semiotic approach?

3. To what extent can a semiotic approach help in decoding the implicit and explicit messages of advertisements? 


\section{$\underline{\text { Literature review }}$}

\section{Semiotics}

Semiotics in its simplest definition is the study of signs. Chandler (2007) maintains that semiotics involves "the study not only of what we refer to as 'signs' in everyday speech, but of anything which 'stands for' something else" (p. 2 ). Chandler also points out that the value of semiotics is related to "its central concern for the investigation of meaning-making and representation which conventional academic disciplines have tended to treat as peripheral" (p. 223). The Swiss linguist Ferdinand de Saussure and the American philosopher Charles Peirce are regarded as the co-founders of semiotics.

As cited in Kress \& van Leeuwen (2006), there are three schools of semiotics in Europe: the Prague School, the Paris School and Halliday's School. These schools applied linguistic ideas to non-linguistic modes of communication. The first depended on developing the work of Russian Formalists by means of providing it with a linguistic basis. The second was based on the application of the ideas of Saussure's semiology to photography, fashion, music and cinema. The third relied on Halliday's systemic functional linguistics which "explores both how people use language in different contexts, and how language is structured for use as a semiotic system" (Eggins, 2004, pp. 20-21).

\section{A sign}

Danesi (2004) defines a sign as "anything - a color, a gesture, a wink, an object, a mathematical equation, etc.- - that stands for something other than itself" (p. 4). In this sense, the word 'white', for example, is a sign because it refers to a particular sort of colour and other things such as innocence. There are two major models of the sign: the Saussurean model and the Peircean model.

Saussure (1916) suggests a dyadic model of the sign consisting of a signifier and a signified. He defines a sign as "the whole that results from the associating of the signifier with the signified" (p. 67). He describes the signifier as something physical such as sounds or letters, and the signified as the image or 
concept referred to by the signifier. Saussure's concept and sound pattern can be clarified in the following figure:

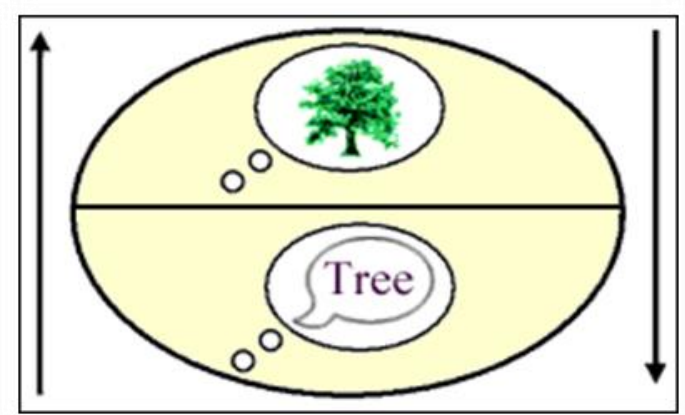

\section{Figure 1: Saussure's concept and sound pattern (Chandler, 2007, p. 15)}

Peirce (1955) introduces a triadic model consisting of a representamen, an interpretant and an object. As Peirce puts it, a sign is "something which stands to somebody for something in some respect or capacity" (p. 99). As cited in Chandler (2007), the representamen, which is similar to Saussure's signifier, is the form taken by the sign; and is called the sign vehicle. An interpretant, which is nearly analogous to Saussure's signified, is the sense made of the sign. An object or a referent is something beyond the sign which it refers to. The following figure illustrates Peirce's triadic model of the sign:

interpretant

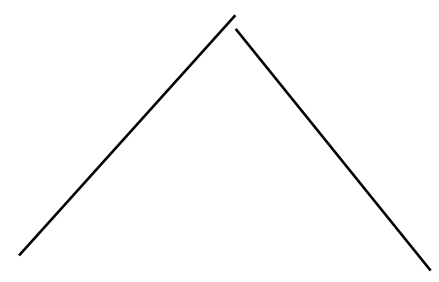

representamen

$$
\text { object }
$$

Figure 2: Peirce's semiotic triangle (Chandler, 2007, p. 30) 
Peirce (1955) argues that there are three modes of relationship —or three types of signs - resulting from his triadic model of the sign. These modes are symbolic, iconic and indexical. Cook (2001) implies that a sign may not be completely symbolic, iconic or indexical. That is, a sign can be all the three modes at the same time.

In the symbolic mode, the relationship between the signifier and the signified is arbitrary or conventional and is not based on any natural link or resemblance. That is, "the signifier does not resemble or cause the signified, but is related to it only by convention" (Dyer, 2009, p. 99). For example, Dyer indicates that a rose is perceived to be a symbol of love although it neither looks like love nor causes it. National flags and traffic lights are other examples of symbolic signs.

In the iconic mode, the relationship between the signifier and the signified is related to likeness or resemblance in that the signifier has some of the qualities of the signified. Chandler (2007) states that resemblance is Peirce's defining feature of iconicity since an iconic sign has features which resemble the object it represents. Photographs, onomatopoeic words and cartoons are examples of icons.

In the indexical mode, the signifier is directly connected to or caused by the signified. According to Peirce (1955), an index is "a sign which refers to the Object that it denotes by virtue of being really affected by that Object" (p. 102). In this regard, smoke can be an index of fire, and a symptom may be an index of a disease. In addition, Dyer (2009) opines that the costume worn by a person can be an index of their profession or social position. 


\section{Advertisements}

Williamson (1978) argues that advertisements are one of the most significant cultural factors which shape and reflect our life today. The cultural symbols which are widely used in advertisements affect the individuals' perception of themselves. That is why Williamson (1978) asserts that "[a]dvertisements are selling us something besides consumer goods: in providing us with a structure in which we, and those goods, are interchangeable, they are selling us ourselves" (p. 13).

One of the key notions in the study of advertisements is ideology. Dyer (2009) refers to the ideological function of advertisements as well as the real messages which are hidden behind their superficial gloss. She states that advertisements "construct ideology within themselves through the intervention of external codes which are located in society." (p. 102). In the same vein, Fairclough (1989) argues that advertisements work ideologically because they play a significant role in building relations, images and the consumer. He opines that "[a]dvertising discourse embodies an ideological representation of the relationship between the producer/advertiser of the product being advertised and the audience, which facilitates the main ideological 'work'" (p. 202). In this sense, ideology has an effect on how people react to advertisements.

Cook (2001) categorises advertisements by means of medium, product, technique and consumer. Examples of the different media in which advertisements can appear are print magazines, newspapers, television, radio and the internet. In terms of the product or service, advertisements can be classified into product and non-product ones. Pertaining to technique, Cook distinguishes between hard selling and soft selling. The former results in a direct appeal while the latter depends on mood. Cook also differentiates between reason and tickle techniques. Reason advertisements present motives for purchase, whereas tickle advertisements appeal to humour, mood and emotion. Advertisements can also be categorized into short copy which have few words, and long copy which have many words. Cook opines that advertisers consider the most significant categorization of advertisements is by consumer. That is, advertising industry classifies people effectively and then targets the classes. 


\section{$\underline{\text { 3. Semiotic studies on advertisements }}$}

In the field of semiotics, Nasir (2018) carried out a study in which he investigated gender discursive patterns in TV commercials in Pakistan. He aimed to highlight the representation of gender-binary relations that existed in Pakistani TV commercials. In addition, he aimed to examine the semiotic interpretation of the roles given to both men and women in those commercials. The corpus of Nasir's study was comprised mainly of seventy TV commercials that were broadcast on famous Pakistani channels. The theoretical framework of Nasir's study was based on the theory of semiotics propounded by Barthes (1977). Nasir applied Dyer's (1982) semiotic analytical model which emphasized the importance of denotative and connotative analysis. He attempted to analyse the relation between the visual description and the socio-cultural values existing in the Pakistani society. Therefore, Nasir's analysis consisted of two main steps. First, he introduced a denotative analysis which dealt with the physical description of the selected commercials. Second, he carried out a connotative analysis in which he identified the major signifiers along with their connotation in the light of the ideological beliefs of the Pakistani society. The findings of Nasir's study indicated that men and women were stereotypically represented. The semiotic modes employed in the investigated commercials signified the conventional roles played by men and women in the Pakistani society. Consequently, Nasir concluded that Pakistani TV commercials reinforced the patriarchal ideological beliefs of the society.

Utilising a socio-pragmatic approach, El-Kalla (2015) analysed print advertisements as semiotic communicative acts. She aimed to study the verbal and nonverbal elements employed in English advertisements in order to find out the elements which helped more in conveying the message of those advertisements to the target audience. Furthermore, she investigated whether gender had an influence on the understanding of advertisements. The data for Elkalla's study consisted of two types. The first comprised the most frequent English advertisements which were published on the internet. The second type of her data was collected by means of a questionnaire directed to a group of 50 male and 50 female informants. El-Kalla applied various theories including Leathers' (1976) nonverbal channels of communication, van Leeuwen's (2005) 
dimensions of semiotics, and Austin's (1965) and Searle's (1969) speech act theory. Moreover, she used Bell's (1995) standards of textuality and Grice's (1975) co-operative principle. Findings of El-Kalla's study showed that nonverbal signs used by advertisers in the selected advertisements were more effective than verbal ones. El-Kalla also concluded that female informants were more aware of nonverbal signs than male informants. However, she added that the difference between the two groups was not significant.

\section{Theoretical framework}

In order to gain optimal understanding of the role played by advertisements in the society, it is essential to delve deeper into the way advertisements organize and form reality, the production of ideology and meanings within the discourse of advertisements, and the way in which images are constructed. This can be achieved through applying a semiotic approach to the analysis of advertisements in terms of signs and sign systems. Accordingly, the model adopted in this research is a blend of Saussure (1916), Barthes (1977), Cook (2001), Chandler (2007) and van Leeuwen's (2005) social semiotics.

\section{Semiotic approaches to the study of advertisements}

In the field of semiotics, the meaning of an advertisement is based on how signs and ideological effects are internally and externally organized. In most advertisements, people and objects are made to be interchangeable. Williamson (1978) argues that in some advertisements, diamonds, for example, are likened to eternal love; thereby creating a sign in which the stone has meaning not in its own terms but in human terms.

Based on Saussure's distinction between langue (language) and parole (speech), advertisements can be seen as the parole or the "ordered combination of verbal and visual signs into messages" (Dyer, 2009, p. 93); and the codes causing the messages to function are the langue. Furthermore, advertisements 
can be analysed in terms of signifiers and signifieds depending on Saussure's (1916) dyadic model of the sign. For instance, the green colour of an advertised product is a signifier referring to a signified such as tranquility. On the whole, Dyer (2009) states that advertisements function at the level of the signifier. In most advertisements, the signifiers are the people who actually use the product. Those people are usually presented by advertisers as good-looking, young, smart and happy.

Barthes (1977) studies the way in which meaning gets into the image through the study of the advertising image since it is full of signs. He explicates that there are three types of messages in an advertisement: a linguistic message, a denoted message and a connoted message. The linguistic message exists in every image as, for instance, in film dialogues in TV commercials. He states that the function of the linguistic message is to enhance some interpretations rather than others, thereby resolving ambiguity that may exist in an image. As to the denotative or the literal message, it is a non-coded iconic message which plays a special role in the formation of the iconic message. Concerning the connotative or symbolic message, it is a coded iconic message which depends on cultural codes.

Cook (2001) claims that Saussure's notions of syntagm and paradigm are applicable to the pictures of advertisements in that "[d]ifferent choices and combinations yield different meanings" (p. 66). In accordance with Cook, Chandler (2007) refers to the significance of the distinction between syntagmatic and paradigmatic relations in carrying out a structuralist semiotic analysis. In this type of analysis, both the horizontal axis as syntagmatic and the vertical axis as paradigmatic can be applied to all sign systems. The syntagmatic analysis examines the surface structure of a text as well as the relationships between its parts. Chandler claims that the paradigmatic analysis reveals the positive or negative connotations connected with each signifier through the use of a particular signifier instead of another.

Cook (2001) maintains that the idea of communication in terms of a simple decoding process is predominant in some semiotic approaches to advertising. As cited in Cook, Saussure claims that the process of creating meaning is based on encoding and decoding. In this respect, a person can encode 
their thoughts into words and convey them to another person that in turn decodes them to get the original meaning. Nevertheless, Cook argues against Saussure's view of a straightforward decoding procedure. He claims that English speakers, for example, may interpret the same advertisement in different ways based on their age, sex, social status, and so on. He adds that linguistic decoding as well as non-linguistic knowledge can create an interpretation which may resemble the sender's intention, but it is not identical to it.

\section{$\underline{\text { 2. Social semiotics }}$}

As van Leeuwen (2005) puts is, social semiotics is considered a distinctive approach to the theory and practice of semiotics. One of the key terms in social semiotics is the notion of 'semiotic resource' which van Leeuwen defines as "the actions and artefacts used for communication whether they are physiologically produced with the vocal apparatus, or with the muscles used for creating gestures and facial expressions, "or by means of technologies - with pen, ink and paper; with computer hardware and software; with fabrics, scissors and sewing machines, etc. Traditionally they were called 'signs'" (p. 3). Nonetheless, the notion of the sign in social semiotics is somewhat different from that used in semiology. Hence, Chandler (2007) emphasizes that social semiotics "has moved beyond the structuralist focus on signifying systems as languages, seeking to explore the use of signs in specific social situations" (p. 8).

van Leeuwen (2005) opines that social semiotics investigates two closely related issues: "the material resources of communication and the way their uses are socially regulated" (p. 93). He also asserts that social semiotics is influenced by functionalism through Halliday's theory of functional grammar that has inspired functional approaches to semiotics. van Leeuwen illustrates that social semiotic analysis has key dimensions which include discourse, genre, style and modality.

Concerning discourse, van Leeuwen (2005) states that it is one of the major concepts in the study of how semiotic resources are utilised in constructing representations indicating what is happening in the world. This 
implies that discourse is a social semiotic approach which is concerned with the 'what' of communication. Regarding genre, it generally refers to a type of text. van Leeuwen defines genres as semiotic resources or templates used for enacting communicative interactions. As to style, van Leeuwen rests upon Oxford Dictionary in defining it as "a manner of writing, speaking or doing, especially as contrasted with the matter to be expressed or thing done" (p. 139). Relating to modality, Chandler (2007) claims that "[m]odality refers to the reality status accorded to or claimed by a sign, text or genre" (p. 65).

\section{$\underline{\text { Sample analysis }}$}

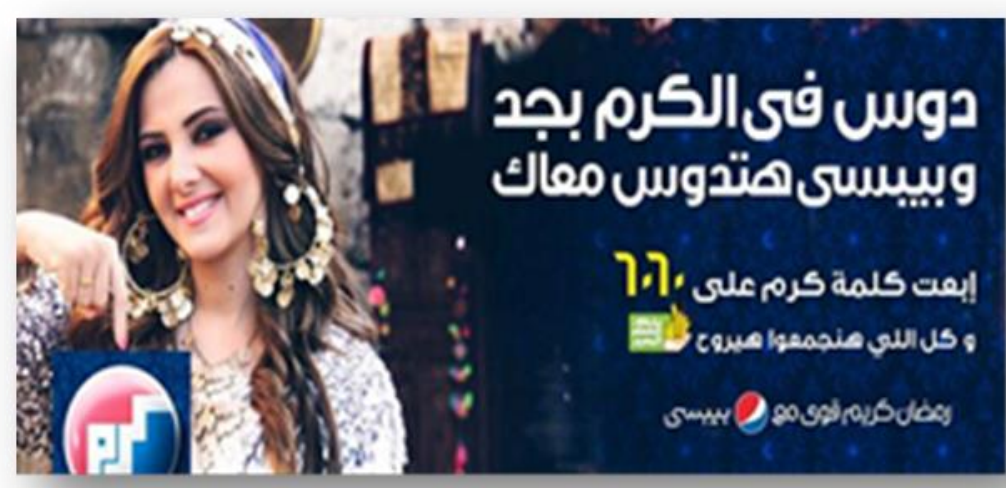

Figure 3

Figure 3 is an example of an Egyptian advertisement which was broadcast on TV during the month of Ramadan. This advertisement includes a lot of signs. First, the word "كرم" karam (i.e., generosity) is a sign deployed by the advertiser to convey the idea that the more Pepsi you drink, the more generous you are. In order to persuade the target audience to buy the advertised product, the advertiser associates it with a positive feature, matching the culture of the Egyptian society. Nevertheless, this feature has nothing to do with the quality of the product itself. Second, the model's exciting and eager look is another sign urging the target 
audience to buy this product so as to be generous. Third, the colours used in the advertisement are also a sign. For example, the model is dressed in bright silver colour to denote a sense of pleasure. Fourth, the model is depicted as a belly dancer who wears a lot of eye make-up to be attractive. It is noteworthy that there is no image of the product itself in that the advertiser focuses more on the image of the female model to attract more viewers to the advertisement.

All in all, the connotative meaning of the signs in Figure 3 is that there is a relationship between drinking Pepsi and being generous. Despite the fact that the advertiser urges the viewers to donate money to the charity by buying Pepsi, he uses a belly dancer to tell them so. Portraying the model as a belly dancer in this advertisement is illogical and not justified. 


\section{$\underline{\text { Conclusion }}$}

Advertisements depict a world full of dreams and fantasy in which people and objects become signs in magazines or on television and are given symbolic meanings. So as to interpret the meanings conveyed through advertisements, different semiotic approaches can be applied. Saussure's (1916) dyadic model of the sign can help in analyzing advertisements at the level of the signifier. Barthes' (1977) classification of messages into linguistic, denoted and connoted can contribute to representing the denotative and connotative meanings embedded in advertisements. Cook's (2001) syntagmatic and paradigmatic analysis is helpful in showing the significance of using a particular signifier instead of another in a given advertisement. van Leeuwen's (2005) notions of discourse, genre, style and modality help in indicating how advertisements affect the target audience. To put it another way, temptation, exaggeration and manipulation are the most prominent features of advertisements nowadays. Some advertisements focus more on appealing to the emotions of the target audience than the goods on offer. That is why the advertised products are often linked to emotions, desires and ideal lifestyles. Besides, it is hard to resist advertisements that offer the opportunity to get perfect relationships, grateful husbands, handsome lovers and happy families. What remains memorable on the part of the target audience is those idealised images rather than the product itself. For example, some people buy the advertised product on the plea that it causes them to be like the signifier in the advertisement. 


\section{References}

Barthes, R. (1977). Image, music, text. New York: Hill \& Wang.

Chandler, D. (2007). Semiotics: The basics (2nd ed.). New York: Routledge. Cook, G. (2001). The discourse of advertising (2nd ed.). New York: Routledge.

Danesi, M. (2004). Messages, signs and meanings: A basic textbook in semiotics and communication. Toronto: Canadian Scholar's Press Inc.

de Saussure, F. (1916). General principles. In B. Charles \& S. Albert (Eds.), Course in general linguistics (pp. 65-77). New York: McGraw-Hill Book Company.

Dyer, G. (2009). Advertising as communication. London: Routledge.

Eggins, S. (2004). An introduction to Systemic Functional Linguistics (2nd ed.). New York: Continuum.

El-Kalla, D. (2015). Advertisements as semiotic communicative acts: A sociopragmatic study (Doctoral dissertation), Suez University, Suez.

Fairclough, N. (1989). Language and power. London: Longman.

Kress, G., \& van Leeuwen, T. (2006). Reading images: The grammar of visual design (2nd ed.). New York: Routledge.

Nasir, M. (2018). A semiotic analysis of gender discursive patterns in Pakistani television commercials. International Journal of English Linguistics, 8(4), 192-207. Retrieved from http://doi.org/10.5539/ijel.v8n4p192

Peirce, C. (1955). Logic as semiotic: The theory of signs. In J. Buchler (Ed.), Philosophical writings of Peirce (pp. 98-119). New York: Dover Publications.

van Leeuwen, T. (2005). Introducing social semiotics. New York: Routledge.

Williamson, J. (1978). Decoding advertisements: Ideology and meaning in advertising. London: Marion Boyars. 